Urszula Kluczyńska

Uniwersytet Medyczny im. Karola Marcinkowskiego w Poznaniu

\title{
Stereotypy i oczekiwania wobec mężczyzn wykonujących zawód pielęgniarza
}

\footnotetext{
Cdy myślimy o pielęgniarstwie, wyobrażamy sobie zwykle kobietę $\checkmark$ i mówimy po prostu „pielęgniarka”. Słowo 'pielęgniarz' nie przystaje do naszych stereotypowych oczekiwań; budzi zdziwienie. A przecież mężczyźni również pracują w tym zawodzie. Gdy zwracam uwagę na nieadekwatność mówienia wyłącznie o pielęgniarkach, spotykam się z zaskoczeniem: przecież pielęgniarka to kobieta. Uzus językowy kojarzy ten zawód z określoną płcią i trudno uciec od tego rodzajowego napiętnowania. Można mówić o pielęgniarstwie, personelu pielęgniarskim, ale ostatecznie i tak wrócimy do słowa 'pielęgniarka'. Czynią tak pacjenci, studenci, często również nauczyciele na kierunkach medycznych. Ta „oczywistość” pojawia się także w języku angielskim, który zazwyczaj uwalnia od rodzajowego naznaczenia. Słowo nurse odnosi się bowiem przede wszystkim do pielęgniarki. By określić mężczyznę uprawiającego ten zawód, należy użyć frazy male nurse, jakby samo nurse nie dostarczało wystarczającej informacji, gdyż pomija - zjakichś względów istotną - kwestię płci.

Podczas gdy w wielu krajach promuje się pielęgniarstwo jako kierunek dla mężczyzn, w Polsce nadal prezentowane jest jako profesja dla kobiet, a pielęgniarz jest ewenementem. Prosty zabieg unaocznia polskie realia. Wpisanie w przeglądarkę internetową frazy male nurse odsyła do stron $\mathrm{z}$ informacjami o wyborze tego zawodu przez mężczyzn, historiach mężczyzn wybierających ową profesję, pismach dla pielęgniarek i pielęgniarzy, stereotypach związanych z omawianym zawodem. W przypadku wpisu „pielęgniarz”, pojawiają się w pierwszej kolejności informacje o molestowaniu pacjentek przez pielęgniarza, nagannym zachowaniu wobec osób starszych, następnie wiele propozycji pracy oraz jedna historia mężczyzny, który wybrał zawód pielęgniarza i położnika, a także informacja, że, ku zaskoczeniu wszystkich, pielęgniarką roku w zachodniopomorskim został pielęgniarz. Kontrast w zestawieniu uzyskanych rezultatów wyszukiwania jest uderzający. Przyczyny, a także skutki takiego postrzegania pielęgniarstwa
} 
są problemem złożonym, uwikłanym w rodzajowe oczekiwania i stereotypy, dlatego uważam, że warto bliżej przyjrzeć się sposobowi traktowania mężczyzn pracujących w pielęgniarstwie.

Celem poniższej analizy jest przegląd literatury przedmiotu dotyczącej sytuacji mężczyzn w zawodzie pielęgniarza ze szczególnym uwzględnieniem dominujących mitów i stereotypów oraz wynikających zeń konsekwencji. Bardzo często zarzuca się polskim naukowcom, że nie bazują na rodzimych badaniach i publikacjach, lecz sięgają do prac powstałych na Zachodzie. Dokonując przeglądu polskiej literatury przedmiotu, dostrzegłam, że tematyka udziału mężczyzn w pielęgniarstwie jest niemal nieobecna ${ }^{1}$. W związku z tym zmuszona byłam oprzeć się na literaturze i badaniach zagranicznych. Analizując materiały dotyczące pracy mężczyzn w zawodzie pielęgniarza, zdecydowałam skupić się głównie na literaturze anglojęzycznej, opisującej omawianą kwestię w Stanach Zjednoczonych, Kanadzie, Australii, Wielkiej Brytanii, Szwecji, Norwegii, ale również w Chinach i Izraelu. Uważam, że mimo różnic kulturowych i społecznych, wyniki te stanowią istotny punkt wyjścia dla polskich badań nad udziałem mężczyzn w pielęgniarstwie.

\section{Wielość męskości i męska dominacja}

W dalszej części skupię się na stereotypach i oczekiwaniach wobec wykonywania przez mężczyzn zawodu pielęgniarza. Kluczowymi kategoriami dla analizy są pojęcia: męskości oraz porządku płci, przy czym to drugie rozumiane jest jako wzajemne relacje i uwarunkowania w obrębie płci kulturowej ${ }^{2}$.

Obecnie dochodzi do zatarcia - oczywistych w przeszłości - rozróżnień w obrębie kategorii płci społeczno-kulturowej. Brak jasności w tym względzie powoduje, iż coraz trudniej wskazać, co znaczy być mężczyzną3. Niemożliwym jest uzyskanie jednoznacznej odpowiedzi na pytanie o istotę męskości, ponieważ, traktując ją jako konstrukt społeczny, można przyjąć, iż „istnieje wiele równoprawnych (i często sprzecznych ze sobą) wersji

${ }^{1}$ Do nielicznych wyjątków można zaliczyć: Małgorzata Fuszara, Dobrze jest być rodzynkiem, czyli mężczyźni w zawodach sfeminizowanych, [w:] red. eadem, Nowi mężczyźni? Zmieniające się modele męskości we wspótczesnej Polsce, Trio, Warszawa 2008, s. 329-360; Wojciech Kapała, Paweł Rucki, Mężczyźni w polskim pielęgniarstwie. Jak widzą i oceniaja swój zawód polscy pielęgniarze, „Pielęgniarstwo Polskie” 2008, nr 1 (27), s. 7-13.

${ }^{2}$ Zob.: Reawyn W. Connell, Masculinities, University of California Press, Berkeley, Los Angeles 1995.

3 Zbyszko Melosik, Kryzys męskości w kulturze wspótczesnej, Wolumin, Poznań, 2002, s. 8. 
męskości"4. Coraz częściej odrzuca się istnienie prawdziwej męskości (i kobiecości), zaznaczając, iż mamy do czynienia z męskościami (z naciskiem na liczbę mnogą), które są społecznie konstruowane ${ }^{5} \mathrm{i}$ wytwarzane w ramach funkcjonującego w określonych kontekstach społecznych dyskursu ${ }^{6}$. Jak twierdzi Reawyn W. Connell, powołując się na Davida D. Gilmore'a: „Nie ma jednego wzorca męskości, który występowałby wszędzie [...]. Musimy mówić o «męskościach», nie męskości. Różne kultury i różne okresy historii odmiennie kształtowały konstrukt męskości”7. Obecnie, dla przykładu, można zauważyć zarówno typ mężczyzny delikatnego, sfeminizowanego, ale także modele męskości oparte na tradycyjnym wzorcu dominacji ${ }^{8}$. Brian McNair zaś dodaje: „W każdym czasie i w każdej kulturze obecne są hierarchie różnych rodzajów męskości, z których jedne są dominujące, a inne podporządkowane; jedne nagradzane, inne karane" 9 . Przekonania dotyczące tego, jaki powinien być mężczyzna, a jaka kobieta są wszechobecne w życiu społecznym. Ich konsekwencją są odmienne oczekiwania w stosunku do osób w zależności od płci - sugerują odmienny zakres zaangażowania w określony typ działań społecznych i obszary aktywności życiowej.

Coraz częściej mówi się o męskościach i kobiecościach, jednak ich wielość uwikłana jest w relację władzy i podporządkowania. To coś więcej niż dominacja mężczyzn nad kobietami, to także dominacja pewnych typów męskości nad innymi. W naszym społeczeństwie większym prestiżem i władzą cieszą się biali, sprawni, heteroseksualni i młodzi mężczyźni ${ }^{10}$, podczas gdy inne ich grupy są marginalizowane ${ }^{11}$. Tradycyjnie ideał męskości związany jest jednak przede wszystkim z twardością i dominacją ${ }^{12}$; to wzorzec męskości, który znajduje się na samej górze hierarchii typów męskości.

\section{Ibidem.}

${ }^{5}$ Michael S. Kimmel, Introduction, [w:] eds. Michael S. Kimmel, Michael A. Messner, Men's Lives, Allyn and Backon, Boston, London 1998, s. xxi.

${ }^{6}$ Por.: Reawyn W. Connell, op. cit.

7 Reawyn W. Connell, The Men and the Boys, University of California Press, Berkeley, Los Angeles 2000, s. 10. Tam, gdzie nie zaznaczono inaczej, cytaty ze źródeł obcojęzycznych podaję w tłumaczeniu własnym.

${ }^{8}$ Zbyszko Melosik, op. cit., s. 8.

9 Brain McNair, Seks, demokratyzacja pożądania i media, czyli kultura obnażania, przeł. Ewa Klekot, Muza S.A., Warszawa 2004, s. 298.

${ }^{10}$ Zob. chociażby: Urszula Kluczyńska, Mężczyźni jako grupa niejednorodna $w$ dostępie do władzy i prestiżu, [w:] red. Krystyna Marzec-Holka, Halina Guzy-Steinke, Kapitał spoleczny a nierówności - kumulacja i redystrybucja, Wydawnictwo Uniwersytetu im. Kazimierza Wielkiego, Bydgoszcz 2009, s. 371-380.

${ }^{11}$ Reawyn W. Connell, The Men..., op. cit., s. 10.

${ }_{12}$ Reawyn W. Connell, Gender and Power: Society, the Person and Sexual Politics, Stanford University Press, Palo Alto 1987, s. 80. 


\section{Historyczna interpretacja obecności mężczyzn w pielęgniarstwie}

Badacze często wskazują na historyczną obecność mężczyzn w pielęgniarstwie, starając się tym samym ugruntować pozycję pielęgniarzy. Analizy wskazują między innymi, że pierwsza szkoła pielęgniarska powołana w Indiach około 250 p.n.e. była przeznaczona wyłącznie dla mężczyzn i kobiety nie miały do niej wstępu, ponieważ nie były „tak czyste” jak mężczyźni ${ }^{13}$. W starożytnej Grecji pielęgniarzami byli również mężczyźni, lecz wykonywali raczej rolę asystentów lekarza. Kobiety natomiast były osobami pielęgnującymi pacjentów $\mathrm{w}$ domu ${ }^{14}$. Wskazuje się także na organizacje religijne, których członkami byli mężczyźni opiekujący się chorymi czy przykłady mężczyzn, którzy w trakcie wojny zgłaszali się jako pielęgniarze wolontariusze ${ }^{15}$.

Można tu dostrzec pewne problematyczne kwestie. Przede wszystkim, kogo określić mianem pielęgniarki/pielęgniarza? Jakimi umiejętnościami, wykształceniem lub kompetencjami muszą legitymować się te osoby? Kobiety podejmowały szereg czynności pielęgniarskich w domach, lecz miały ograniczony dostęp do edukacji, także społeczno-kulturowe uwarunkowania zamykały je w sferze prywatnej. Można zatem stwierdzić, że kobiety nie miały możliwości wyjścia poza sferę domową, w związku z czym realizowały zadania pielęgniarskie w jej obrębie. Mężczyźni, odgrywający zdaniem badaczy istotną rolę w pielęgniarstwie ${ }^{16}$, byli bardziej widoczni od kobiet „ukrytych” $\mathrm{w}$ domach. $\mathrm{Z}$ czasem jednak kobiety coraz liczniej pojawiały się $\mathrm{w}$ zawodzie, choć można też uznać, że to mężczyźni zaczęli się z niego wycofywać. Powodem był przede wszystkim niski prestiż oraz fakt, że pielęgniarstwo uprawiały osoby o wątpliwej reputacji i uczciwości, niskim statusie społecznym, niewykształcone, decydujące się na ten zawód wyłącznie ze względów ekonomicznych ${ }^{17}$. Historycy określają często okres pomiędzy XVI a XIX wiekiem jako czas mrocznego średniowiecza pielęgniarstwa ${ }^{18}$.

${ }^{13}$ Lucille A. Joel, Kelly's Dimension of Professional Nursing, The McGraw-Hill Companies 2003. Podaję za: Kenny Thompson, Daren Vertein, Rethinking Gender Stereotypes in Nursing, dostępne przez: http://www.minoritynurse.com/article/rethinking-gender-stereotypes-nursing (30.06.2013).

14 Despina Sapountzi-Krepia, European Nursing History: Nursing Care Provision and Nursing Training in Greece and Ancient Times Until the Creation of the Modern Greek State, „ICU and The Nursing Web Journal” 2004, no. 18, s. 1-4.

${ }^{15}$ Chad E. O'Lynn, History of Men in Nursing. A Review, [w:] eds. Chad E. O’Lynn, Russell E. Tranbarger, Men in Nursing: History, Challenges, and Opportunities, Springer Publishing Company, New York 2007, s. 5-23.

${ }^{16}$ Zob.: Carolyn Macintosh, A Historical Study of Men in Nursing, „Journal of Advanced Nursing" 1997, no. 26, s. 232-236, 232; Ronald Gordon Sclater Brown, Robert William Howard Stones, The Male Nurse, Willmer Brothers, Birkenhead 1973; John M. Mellish, A Basic History of Nursing, Butterworth, Durban 1984.

${ }^{17}$ Carolyn Macintosh, op. cit., s. 232.

${ }^{18}$ Chad E. O'Lynn, op. cit., s. 5-23. 
Do istotnych zmian doszło dopiero w połowie XIX wieku pod wpływem działalności Florence Nightingale (1820-1910), która określana jest jako twórczyni nowoczesnego pielęgniarstwa. Na ten okres datuje się również oficjalne powiązanie pielęgnacji z kobiecością. Twierdzono wręcz wówczas, że pielęgnowanie jest czymś naturalnym dla kobiety, wpisane w jej rolę i pozwalające na samorealizację ${ }^{19}$. Zawód pielęgniarki dawał również kobietom możliwość wyjścia poza sferę prywatną, choć wymagał realizowania stereotypowo kobiecych zadań. Owo wyjście wiązało się jednak w społecznej świadomości z pewnym poświęceniem, bowiem do lat sześćdziesiątych XX wieku większość pielęgniarek była niezamężna ${ }^{20}$. Badacze twierdzą, że pielęgniarstwo zdominowały kobiety i do połowy XX wieku mężczyźni często nie mieli możliwości aplikowania do szkół pielęgniarskich ${ }^{21}$. Wyjątek stanowiło pielęgniarstwo psychiatryczne, gdzie siła fizyczna stanowiła istotny atrybut i w związku z tym specjalizację tę definiowano jako właściwą dla tradycyjnie pojmowanej męskości ${ }^{22}$.

Warto zastanowić się, co spowodowało zmniejszenie liczby mężczyzn w pielęgniarstwie. Odpowiedź nie jest prosta i jednoznaczna. Jedną z przyczyn z pewnością było wyjście kobiet ze sfery prywatnej i wkroczenie do zawodu, który z czasem zaczął być kojarzony niemal wyłącznie z kobiecością, podległością i służbą innym. Jednocześnie doszło do obniżenia prestiżu zawodu, który w związku z tym mężczyźni porzucili bez żalu, zwłaszcza, że owemu zjawisku towarzyszyła dyskryminacja przy przyjmowaniu do szkół pielęgniarskich ${ }^{23}$. Największym ograniczeniem jednak były (i nadal są) społeczne oczekiwania wobec mężczyzn. Chęć uprawiania zawodu, który historycznie i kulturowo traktowany jest jako kobiecy budzi zaniepokojenie. Postrzegane jest to bowiem jako dobrowolna decyzja o symbolicznym przejściu do grupy kobiet poprzez przyjęcie zachowań i podejmowanie działań definiowanych jako kobiece, a zatem plasowanych niżej w hierarchii płci. Takie „przejście” może być traktowane jak zagrożenie dla tradycyjnego porządku społecznego, ponieważ zrównuje kobietę i mężczyznę, zaburzając hierarchię społeczną i budząc lęk grupy uprzywilejowanej - w tym przypadku mężczyzn. Reakcją na decyzje mężczyzn podejmujących zawód definiowany społecznie jako kobiecy (a zatem podległy) jest próba wykluczenia pielę-

${ }^{19}$ Carolyn Macintosh, op. cit.; Chad E. O’Lynn, op. cit.

${ }^{20}$ Jeremy Jolley, Now and Then. Nurse, I Want My Daddy, „Pediatric Nurse” 2008, no. 20 (10), s. 11.

${ }^{21}$ Jannetta MacPhail, Men In Nursing, [w:] eds. Janet Ross-Kerr, Jannetta MacPhail, Canadian Nursing: Issues and Perspectives, Mosby-Yearbook, St. Louis 1997, s. 74-81; Joan Evans, Men Nurses: A Historical and Feminist Perspective, „Journal of Advanced Nursing” 2004, no. 47 (3), s. 321-328.

${ }^{22}$ Joan Evans, op. cit.

${ }^{23}$ Ibidem, s. 324. 
gniarzy z grupy uprzywilejowanej i zepchnięcia ich do kategorii męskości podporząadkowanej. Zjawisko to ugruntowują określone mity i stereotypy dotyczące mężczyzn w zawodzie pielęgniarza.

\section{Społeczne stereotypy dotyczące mężczyzn w pielęgniarstwie}

Istnieje przekonanie o naturalności wykonywania zawodu pielęgniarki przez kobiety, które skutkuje wytworzeniem pewnych przekonań o pielęgniarzach. Przede wszystkim obecność mężczyzn w tym zawodzie łączona jest z naruszeniem społecznego tabu. Ze względu na założenie „nienaturalności” uprawiania zawodu pielęgniarza, mężczyźni go uprawiający nie są uważani za „prawdziwych mężczyzn”. Także nieatrakcyjne warunki pracy, wynikające ze stosunkowo niskich zarobków i wielogodzinnej pracy zmianowej, postrzegane są jako zniechęcające mężczyzn ${ }^{24}$.

$\mathrm{Z}$ całą pewnością niebagatelną rolę w społecznej percepcji omawianego zawodu odgrywa przekonanie, że pielęgnowanie i opieka są zadaniami kobiecymi; są formą posługi, ofiary i elementami kobiecej roli. Zakłada się, że kobiety nie potrzebują nawet edukacji pielęgniarskiej, albowiem zadania związane z pielęgnowaniem i opieką są dla nich tak naturalne, że niemal instynktowne ${ }^{25}$, w odróżnieniu od mężczyzn, których stereotypowo postrzega się jako nieposiadających predyspozycji emocjonalnych i komunikacyjnych. Mężczyzn określa się jako mniej empatycznych oraz rzadziej okazujących emocje czy wsparcie. Jednak takie zachowania nie muszą wynikać z niechęci do okazywania uczuć, ale blokowania oraz przekonania, że ich uzewnętrznianie będzie nieprzychylnie traktowane przez pacjentów. Objęcie ramieniem czy delikatny dotyk są określane jako zachowania właściwe dla kobiet - w tym pielęgniarek - ale nie dla mężczyzn. Być może dlatego brytyjskie badania wykazują, że pielęgniarze mają wrażenie, że pielęgniarki są bardziej wrażliwe na uczucia pacjentów ${ }^{26}$, choć analizy nie potwierdzają takiej zależności. Słuszne wydaje się twierdzenie Joan Evans, że sposób pielęgnowania należy łączyć raczej z indywidualną formą ekspresji, a nie płcią ${ }^{27}$.

W społecznym odbiorze wybór zawodu pielęgniarza prowadzi do degradacji i powiązania ze stereotypowym wyobrażeniem kobiecości, definiowanej poprzez odniesienie do męskości. Tradycyjna męskość określana jest przez szereg opozycji. Według Elisabeth Badinter, „być mężczyzną to znaczy nie

${ }^{24}$ Carolyn Macintosh, op. cit.

25 Joan Evans, op. cit., s. 226-231.

${ }_{26}$ Zob.: Frank Milligan, The Concept of Care in Male Nurse Work: An Ontological Hermeneutic Study in Acute Hospitals, „Journal of Advanced Nursing” 2001, vol. 35, issue 1, s. 7-16; Joan Evans, Cautious Caregivers: Gender Stereotype and Sexualization of Men Nurses’ Touch, „Journal of Advanced Nursing” 2002, no. 40 (4), s. 441-448.

${ }^{27}$ Joan Evans, Cautious Caregivers..., op. cit. 
być kobiecym, uległym, zależnym, poddanym, nie być homoseksualistą; nie być zniewieściałym $\mathrm{w}$ wyglądzie zewnętrznym i zachowaniu; nie mieć zbyt bliskich stosunków z innymi mężczyznami; nie być impotentem" ${ }^{28}$. Jak już wspomniałam, decyzja o podjęciu „kobiecego” zawodu przybliża do kobiecości, skutkując spadkiem pozycji pielęgniarza w oczach innych mężczyzn. Pielęgniarz staje się niejako mężczyzną podejrzanym, którego mężczyźni hołdujący dominującym wzorcom starają się określić jako „niemęskiego” poprzez przypisanie mu tego, czego „prawdziwy mężczyzna” powinien unikać: uległości, zależności, bycia gejem, bliskości z innymi mężczyznami.

Jedną z najczęstszych prób degradacji statusu pielęgniarzy w hierarchii męskości jest użycie względem nich określenia 'gej', a zatem zepchnięcie ich do kategorii męskości podporządkowanej ${ }^{29}$. Jak zauważa Reawyn W. Connell, w ramach hierarchii męskości mężczyźni heteroseksualni dominują nad homoseksualnymi. Chodzi tu nie tylko dominację o charakterze kulturowym, lecz przejawiającą się w szeregu praktyk społecznych. Homoseksualistów można określić jako najbardziej represjonowaną grupę mężczyzn, umieszczaną na samym dole hierarchii męskości. Zgodnie z patriarchalną ideologią, homoseksualiści są uosobieniem wszystkiego, co przeczy idei dominującej męskości - „od wymagającego gustu w dekoracji domu, po analną przyjemność" 30 .

Niedobór mężczyzn w zawodzie pielęgniarza nie wynika z nadreprezentacji kobiet, to raczej próba obrony hierarchii męskości przez innych mężczyzn. Kobiety, socjalizowane zgodnie z hierarchią zachowań przypisywanych obu płciom, internalizują normy i wartości patriarchalnego społeczeństwa i na różne sposoby dowartościowują mężczyzn pielęgniarzy, ułatwiając im awans w hierarchii zawodowej. $Z$ drugiej strony, funkcjonujące stereotypy czynią takiego mężczyznę mniej męskim, czyli określają go jako mężczyznę, który nie jest uosobieniem hegemonicznej męskości ${ }^{31}$. Twórcy zachodniej reklamy, mającej zachęcić mężczyzn do wyboru pielęgniarstwa, starają się przełamać ten sposób postrzegania i stosują hasło, które w wolnym tłumaczeniu brzmi: „Czy jesteś wystarczająco męski, by zostać pielęgniarzem?” W reklamie zobaczyć można mężczyzn, którzy stanowią uosobienie dominującej męskości: są muskularni, pewni siebie, są sportowcami (bohaterami), zawłaszczają przestrzeń. Nie mniej istotny, a może nawet bardziej, bo jednoznaczny, jest tekst pod zdjęciem informujący, że pielęgniarstwo to obszar realizowania kariery zawodowej, inteligencji, odwagi, umiejętności

${ }_{28}$ Elisabeth Badinter, XY: tożsamość mężczyzny, przeł. Grzegorz Przewłocki, WAB, Warszawa 1993, s. 30.

${ }^{29}$ Reawyn W. Connell, Masculinities..., op. cit.

${ }^{30}$ Ibidem, s. 78.

${ }^{31}$ Ibidem. 
i możliwości ${ }^{32}$. Taki sposób prezentowania pielęgniarstwa ma zaprzeczać społecznie funkcjonującym wyobrażeniom i stereotypom (między innymi pielęgniarza-geja); ma przedefiniować pewne znaczenia i oczekiwania, ale jednocześnie utwierdza w konieczności realizowania hegemonicznej męskości. Takiego pielęgniarza mają widzieć przede wszystkim inni mężczyźni.

Stereotypowe postrzeganie pielęgniarzy jako gejów dotyczy zwłaszcza mężczyzn, którzy nie są żonaci (lub nie noszą obrączki jako oznaki heteroseksualności) i nie posiadają dzieci. Pojawiają się tu bowiem obawy dwojakiego rodzaju: z jednej strony niepokój pacjentów i pacjentek, bazujący przede wszystkim na stereotypach pielęgniarz-gej lub agresor seksualny, z drugiej strony zaś dyskomfort odczuwany przez pielęgniarzy i obawa przed błędną interpretacją ich dotyku, skutkującą oskarżeniem o nieodpowiednie zachowanie lub molestowanie seksualne. Te obawy powodują, że pielęgniarze stosują określone strategie: wydłużanie czasu kontaktu przed dotknięciem pacjentki w celu zbudowania relacji zaufania; zachowanie odpowiedniego stopnia formalności poprzez chociażby uścisk dłoni; podtrzymywanie tradycyjnego wizerunku personelu pielęgniarskiego ( $w$ tym noszenie uniformu), co legitymizuje rolę mężczyzny jako pielęgniarza; pracowanie w zespole z kobietami w sytuacjach, które można by określić jako niebezpieczne; kierowanie pielęgniarki do zadań wymagających dotyku intymnych części ciała; modyfikowanie procedury tak, by minimalizować ekspozycję i konieczność dotyku intymnych części ciała; stosowanie humoru i żartów ${ }^{33}$.

Z badań Joan Evans wynika, że pielęgniarze zakreślają pewne reguły „bezpiecznego” dotyku. W przypadku, gdy pacjentami są mężczyźni, mówią o konieczności akceptowania pewnych męskich norm, określanych mianem „kodu”, które utwierdzają pacjenta w przekonaniu, że pielęgniarz nie jest gejem i jego dotyk nie ma seksualnego podtekstu. Przestrzeganie tych zasad daje pacjentom komfort, co powoduje, że akceptują mężczyznę w roli pielęgniarza. Pielęgniarze przyznają też, że czują się bardziej komfortowo, gdy dotykają osób starszych i poważnie chorych. Największy dyskomfort zaś odczuwają, gdy pacjentkami są nastolatki lub atrakcyjne kobiety. Okazuje się zatem, że dotyk ma płeć ${ }^{34}$. Z kolei pielęgniarz opiekujący się dziećmi, budzi podejrzenia o pedofilię. Założenie to wynika ze stereotypowego przekonania, że to kobieta jest osobą, która powinna się opiekować innymi, w tym dziećmi.

${ }^{32}$ Can We Stop the I'm-a-Male-Nurse-Who-Isn't-Gay-Contrary-to-the-Stereotype Routine?; dostępne przez: http://torontoemerg.wordpress.com/2010/11/o2/can-we-stopthe-im-a-male-nurse-who-isnt-gay-contrary-to-the-stereotype-routine/ (04.07.2013).

33 Joan Evans, Cautious Caregivers..., op. cit., s. 441-448; Murray J. Fisher, „Being a Chameleon”: Labour Processes of Male Nurses Performing Bodywork, „Journal of Advanced Nursing" 2009, no. 65 (12), s. 2668-2677.

34 Joan Evans, Cautious Caregivers..., op. cit. 
Pielęgniarstwo łączone jest z kobiecością, natomiast zawód lekarza z męskością. Bycie lekarzem daje wyższy status, władzę i dochód. W związku z tym najczęściej postrzega się te dwa zawody właśnie przez pryzmat opozycji płci. Lekarzem w powszechnym przekonaniu jest mężczyzna, pielęgniarką kobieta. Sytuacja odwrotna nie jest już tak oczywista i oczekiwana. Należy jednak zauważyć, że inaczej postrzega się lekarkę, a inaczej pielęgniarza. Lekarka traktowana jest najczęściej jako ta, która coś osiągnęła i jest jedną wśród mężczyzn, pielęgniarz postrzegany jest jako ten, który z jakichś (niejasnych) względów zrezygnował z władzy i zgodził się na niższą pozycję w hierarchii; zrównał się z kobietami. Funkcjonuje przekonanie, że mężczyzna wybrał zawód pielęgniarza tylko dlatego, że nie udało mu się dostać na studia lekarskie i że wkrótce prawdopodobnie podejmie kolejną próbę, a pielęgniarstwo jest tylko substytutem lub rozwiązaniem czasowym. Badacze zauważają również, że lekarze inaczej traktują pielęgniarzy niż pielęgniarki ci pierwsi postrzegani są jako bardziej kompetentni. Skutkuje to nadmierną identyfikacją pielęgniarzy z lekarzami, czego efektem jest rozczarowanie wynikające z niższego statusu i zarobków ${ }^{35}$.

Badania wykazują, że pielęgniarze dominują w pewnych specjalizacjach, zwłaszcza tam, gdzie możliwe są wyższe dochody i większy prestiż ${ }^{36}$. Istnieje bowiem społeczne przekonanie, że mężczyźni mają większe predyspozycje, by pracować w określonych sferach. Joan Evans zwraca uwagę na fakt, że na Zachodzie pielęgniarze częściej wybierają następujące dziedziny: psychiatrię, ze względu na siłę fizyczną; anestezjologię, w związku z biegłością techniczną i autonomią; intensywną terapię i pracę na oddziałach ratunkowych, w związku z umiejętnościami technicznymi, adrenaliną i koniecznością opanowywania emocji. Nie wybierają natomiast pracy na oddziałach położniczych i ginekologicznych ${ }^{37}$. Unikają też specjalizacji, gdzie częściej wymagane jest dotykanie pacjentów, zwłaszcza kobiet i zwłaszcza w okolicach stref intymnych ${ }^{38}$.

\section{Podsumowanie}

Podkreślanie obecności mężczyzn w historii pielęgniarstwa może być sposobem uprawomocniania ich obecności w zawodzie i zachęcania do jego uprawiania. Wkroczenie mężczyzn do pielęgniarstwa, stereotypowo określanego jako zawód kobiecy, może być potraktowane przez kobiety jako próba

35 Christine L. Williams, Hidden Advantages for Men in Nursing, „Nursing Administration Quarterly" 1995, no. 19 (2), s. 63-70.

${ }^{36}$ Ibidem.

37 Joan Evans, Men in Nursing..., op. cit., s. 226-231.

${ }^{38}$ Joan Evans, Cautious Caregivers..., op. cit., s. 441-448. 
jego przejęcia w momencie, gdy staje się on lepiej płatny niż w przeszłości, bardziej prestiżowy, a lepiej wykształcony personel pielęgniarski uzyskuje coraz większą autonomię działania. Z drugiej strony, mogą pojawić się obawy, że mężczyźni zmienią pielęgniarstwo i utraci ono swój obecny charakter, który kojarzony jest z troską, opieką i empatią. Jest to podejście bazujące na stereotypach, ale mogące silnie oddziaływać na niechęć do wzrostu liczby mężczyzn w zawodzie. Zachodnie kampanie medialne nakłaniające mężczyzn do zatrudnienia w pielęgniarstwie mogą być próbą otwarcia zawodu i przeciwdziałania dyskryminacji ze względu na płeć, ale także próbą zachęcenia do pracy, która nie cieszy się zbyt wysokim prestiżem, a jest pracą obciążającą fizycznie i psychicznie. Kobiety mogą jednak obawiać się odebrania im pewnej sfery, która wcześniej zarezerwowana niemal wyłącznie dla nich, stanowiła ich bastion i dawała możliwość realizacji zawodowej. Z jednej strony można spotkać się z przekonaniem, że wzrost liczby mężczyzn w zawodzie zwiększy jego prestiż, z drugiej, że pielęgniarstwo nie potrzebuje mężczyzn, by podnieść swój status. Nie oznacza to, że nie powinno być mężczyzn w pielęgniarstwie. Najważniejsze jest, by wybór zawodu wynikał z indywidualnych preferencji, potrzeb i sposobów samorealizacji oraz został uwolniony od ograniczających stereotypów.

\section{BIBLIOGRAFIA}

Badinter Elisabeth, XY: tożsamość mężczyzny, przeł. Grzegorz Przewłocki, WAB, Warszawa 1993.

Brown Ronald Gordon Sclater, Robert William Howard Stones, The Male Nurse, Willmer Brothers, Birkenhead 1973.

Can We Stop the I'm-a-Male-Nurse-Who-Isn't-Gay-Contrary-to-the-Stereotype Routine?; dostępne przez: http://torontoemerg.wordpress.com/2010/11/o2/can-we-stop-theim-a-male-nurse-who-isnt-gay-contrary-to-the-stereotype-routine/ (04.07.2013).

Connell Reawyn W., Gender and Power: Society, the Person and Sexual Politics, Stanford University Press, Palo Alto 1987.

Connell Reawyn W., Masculinities, University of California Press, Berkeley, Los Angeles 1995.

Connell Reawyn W., The Men and the Boys, University of California Press, Berkeley, Los Angeles 2000, s. 10.

Evans Joan, Cautious Caregivers: Gender Stereotype and Sexualization of Men Nurses' Touch, „Journal of Advanced Nursing” 2002, no. 40 (4).

Evans Joan, Men Nurses: A Historical and Feminist Perspective, „Journal of Advanced Nursing” 2004, no. 47 (3).

Fisher Murray J., „Being a Chameleon”: Labour Processes of Male Nurses Performing Bodywork, „Journal of Advanced Nursing” 2009, no. 65 (12).

Fuszara Małgorzata, Dobrze jest być rodzynkiem, czyli mężczyźni w zawodach sfeminizowanych, [w:] red. eadem, Nowi mężczyźni? Zmieniające się modele męskości we wspótczesnej Polsce, Trio, Warszawa 2008. 
Joel Lucille A., Kelly's Dimension of Professional Nursing, The McGraw-Hill Companies 2003.

Jolley Jeremy, Now and Then. Nurse, I Want My Daddy, „Pediatric Nurse” 2008, no. 20 (10).

Kapała Wojciech, Paweł Rucki, Mężczyźni w polskim pielęgniarstwie. Jak widzą i oceniaja swój zawód polscy pielęgniarze, „Pielęgniarstwo Polskie” 2008, nr 1 (27).

Kimmel Michael S., Introduction, [w:] eds. Michael S. Kimmel, Michael A. Messner, Men's Lives, Allyn and Backon, Boston, London 1998.

Kluczyńska Urszula, Mężczý́ni jako grupa niejednorodna $w$ dostępie do władzy i prestiżu, [w:] red. Krystyna Marzec-Holka, Halina Guzy-Steinke, Kapitat spoteczny a nierówności - kumulacja i redystrybucja, Wydawnictwo Uniwersytetu im. Kazimierza Wielkiego, Bydgoszcz 2009.

Macintosh Carolyn, A Historical Study of Men in Nursing, „Journal of Advanced Nursing” 1997, no. 26.

MacPhail Jannetta, Men In Nursing, [w:] eds. Janet Ross-Kerr, Jannetta MacPhail, Canadian Nursing: Issues and Perspectives, Mosby-Yearbook, St. Louis 1997.

McNair Brain, Seks, demokratyzacja pożądania i media, czyli kultura obnażania, przeł. Ewa Klekot, Muza S.A., Warszawa 2004.

Mellish John M., A Basic History of Nursing, Butterworth, Durban 1984.

Melosik Zbyszko, Kryzys męskości w kulturze wspótczesnej, Wolumin, Poznań, 2002.

Milligan Frank, The Concept of Care in Male Nurse Work: An Ontological Hermeneutic Study in Acute Hospitals, „Journal of Advanced Nursing” 2001, vol. 35, issue 1.

O’Lynn Chad E., History of Men in Nursing. A Review, [w:] eds. Chad E. O'Lynn, Russell E. Tranbarger, Men in Nursing: History, Challenges, and Opportunities, Springer Publishing Company, New York 2007.

Sapountzi-Krepia Despina, European Nursing History: Nursing Care Provision and Nursing Training in Greece and Ancient Times Until the Creation of the Modern Greek State, „ICU and The Nursing Web Journal” 2004, no. 18.

Thompson Kenny, Daren Vertein, Rethinking Gender Stereotypes in Nursing, dostępne przez: http://www.minoritynurse.com/article/rethinking-gender-stereotypes-nursing (30.06.2013).

Williams Christine L., Hidden Advantages for Men in Nursing, „Nursing Administration Quarterly"1995, no. 19 (2). 